\title{
Clinical, Radiographical and Histological Evaluation of an Unusual Regional Odontodysplasia Case
}

\author{
Sıradışı Bir Rejyonel Odontodisplazi \\ Vakasının Klinik, Radyografik ve \\ Histolojik Olarak Değerlendirilmesi
}

\author{
Melek D. TURGUT, ${ }^{a}$ \\ Berna ÇELIK, ${ }^{a}$ \\ Ayşegül NAZiKOĞLU, MD, ${ }^{b}$ \\ Atilla Stephan ATAÇ, \\ Sevda MÜFTÜOĞLUb

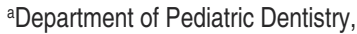 \\ Hacettepe University \\ Faculty of Dentistry, \\ bDepartment of \\ Histology and Embriyology, \\ Hacettepe University \\ Faculty of Medicine, Ankara \\ Bu çalışma, Türk Pedodonti Derneği \\ 15. Bilimsel Kongresi (17-24 Ekim, \\ Antalya)'nde poster olarak sunulmuştur. \\ Geliş Tarihi/Received: 06.05 .2009 \\ Kabul Tarihi/Accepted: 26.09 .2009 \\ Yazışma Adresi/Correspondence: \\ Melek D. TURGUT \\ Hacettepe University \\ Faculty of Dentistry, \\ Department of Pediatric Dentistry, \\ Ankara, \\ TÜRKIYE/TURKEY \\ melekturgut@yahoo.com
}

doi:10.5336/medsci.2009-13335

Copyright ( $\odot 2011$ by Türkiye Klinikleri

\begin{abstract}
Regional odontodysplasia (RO) is an unusual developmental anomaly which usually affects unilateral maxillary teeth of primary or permanent dentition. It is common in females and has typical clinical, radiographical and histological findings. In the present case, an unusual type of RO has shown. The patient was a 5-year-old male and the involved tooth was the primary mandibular right central incisor. Clinical findings of yellow-brown discoloration, malformation, malposition and severe mobility of the involved tooth were detected. A "ghost-like" appearance of the tooth which is one of the typical features of the abnomality was noticed radiographically. The involved primary tooth was extracted and evaluated histologically. The histological analysis also confirmed the diagnosis of RO. In this case report, history and clinical, radiographical and histological features were discussed.
\end{abstract}

Key Words: Odontodysplasia; histology

ÖZET Rejyonel odontodisplazi (RO) genellikle süt veya daimi dişlerde tek taraflı maksiller dişleri etkileyen, nadir görülen, gelişimsel bir anomalidir. Kadınlarda sık görülür ve tipik klinik, radyografik ve histolojik bulguları mevcuttur. Bu vakada, sıradışı bir RO tipi ortaya konmaktadır. Hasta beş yaşında bir erkek çocuk olup tutulan diş süt mandibular sağ orta kesici diştir. Tutulan dişte saptanan klinik bulgular sarı-kahverengi renk değişimi, malformasyon, malpozisyon ve şiddetli mobiliteydi. Anomalinin tipik özelliklerinden biri olan dişin "hayalet benzeri" görünümü radyografik olarak tespit edildi. Tutulan süt dişi çekildi ve histolojik olarak değerlendirildi. Histolojik analiz RO tanısını doğruladı. Bu olgu sunumunda, hastanın öyküsü, klinik ve radyografik bulguları ve histolojik özellikleri tartışılmaktadır.

Anahtar Kelimeler: Odontodisplazi; histoloji

Turkiye Klinikleri J Med Sci 2011;31(1):274-9

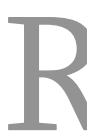
egional odontodysplasia $(\mathrm{RO})$ is a non-hereditary developmental abnomality affecting epithelial and mesenchymal-derived dental tissues. ${ }^{1}$ It is an unusual abnomality and its prevalence is not known since the existing literature regarding $\mathrm{RO}$ is limited to cases reports. ${ }^{2}$ Although the etiology of RO is not clear, possible causes including viral infections, medications taken during pregnancy, facial asymmetry, local trauma, metabolic and vascular disturbances, somatic and neural mutations have been accused. ${ }^{3-5}$

$\mathrm{RO}$ can be diagnosed with clinical, radiographical and histological findings. ${ }^{6}$ In general, contiguous and unilateral maxillary teeth are involved, 
with an incidence higher in females. ${ }^{7}$ Clinically delayed, failed or partial eruption of discolored and atypically shaped teeth are encountered. ${ }^{2,8-10}$ Radiographically, the affected teeth appear as "ghost teeth" since the radiopacity and thickness of enamel and dentin are reduced and pulp chamber is enlarged. ${ }^{11}$

In the following case, clinical, radiographical and histological features of an unusual type of RO case are presented.

\section{CASE REPORT}

A 5-year-old male patient referred to the department of pediatric dentistry with the complaint of discoloration and mobility of his primary mandibular right central incisor. It is medical history revealed that he had neurological problems including epilepsy, ophthalmologic problems, walking and balance disturbances since he had fallen from $3^{\text {rd }}$ floor at the age of 22 months. He was receiving anti-epileptic medications.

Intraoral examination, revealed that all primary teeth had erupted. Yellow-brown discoloration, a cleft located on the incisal portion of the crown, malformation of the incisal portion of the buccal surface and severe mobility of the primary mandibular right central incisor were noticed. The tooth was partially erupted and almost horizontally positioned (Figure 1).

The parents reported that primary mandibular right central incisor almost horizontally erupted when the patient was 7-8 months old and was narrower than the other primary teeth. The tooth became mobile and had small abscesses which were spontaneously ruptured and reformed after trauma. The parents could not remember the exact time of the discoloration but stated that the tooth was white in color after the eruption.

The periapical radiograph revealed a short and narrow root, loss in lamina dura and the surrounding alveolar bone, and a resorption cavity located in the mesial aspect of the root. A cleft extending from the incisal edge down to the widened pulp chamber and less radiopacity of the enamel and dentin were also noticed (Figure 2).
As the tooth was mobile, the treatment plan consisted of extraction of the tooth under local anesthesia.

After extraction, the tooth was evaluated histologically. For this purpose, the tooth was fixed in $10 \%$ neutral formalin solution for $72 \mathrm{~h}$. Then, it was decalcified in de Castro solution for 30 days. ${ }^{12}$ Decalcified tooth sample was embedded in paraffin and serially sectioned in $5 \mu \mathrm{m}$ thickness. The slices were stained with hematoxylin \& eosin (H\&E) and Masson's trichrom (MT), and examined under a reflection contrast microscope (Leica, DMR-RCM, Wetzlar, Germany). The images were transferred to the computer with a digital camera (Leica DC200, Wetzlar, Germany).

In the histological examination, enamel could not be evaluated because of the decalcification procedures. A large cleft was observed at the outer layer of the tooth extending into the pulp. In addition, narrower clefts located in the dentin were detected (Figure 3).

The pulp was necrotic and no odontoblasts were observed. In the pulp chamber, a large, calcified amorphous globule stained gray in color with H\&E was observed. That was stained as red-brown along with some calcified areas in dentin with MT (Figures 4, 5).

In dentin, reduction in tubule numbers and variability in tubule orientation (longitudinal, oblique and horizontal orientations) were noticed. In addition, increase in interglobuler dentin and enlargement of the predentin layer were seen (Figures 6, 7). There were no carious tooth tissue and bacteria.

After the evaluation of the root part of the tooth, it was apparent that the root portion was affected less from degenerative changes compared to the coronal portion. In the apical part, calcified and calcifying connective tissues were noticed (Figure 8, 9).

An informed consent was obtained from the parents to publish all clinical, radiographical and histological findings of the patient.

\section{DISCUSSION}

Up to date, several case reports with RO have been reported. According to some of those cases, the ab- 


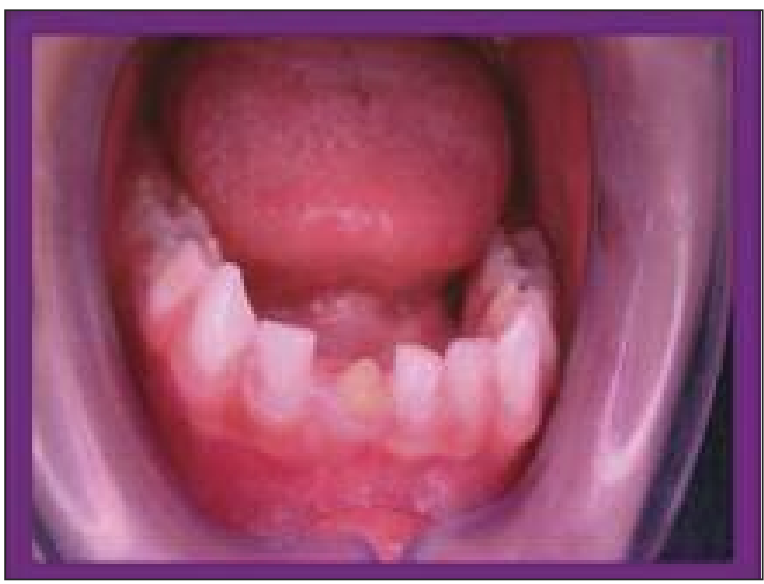

FIGURE 1: Intraoral view of the patient.

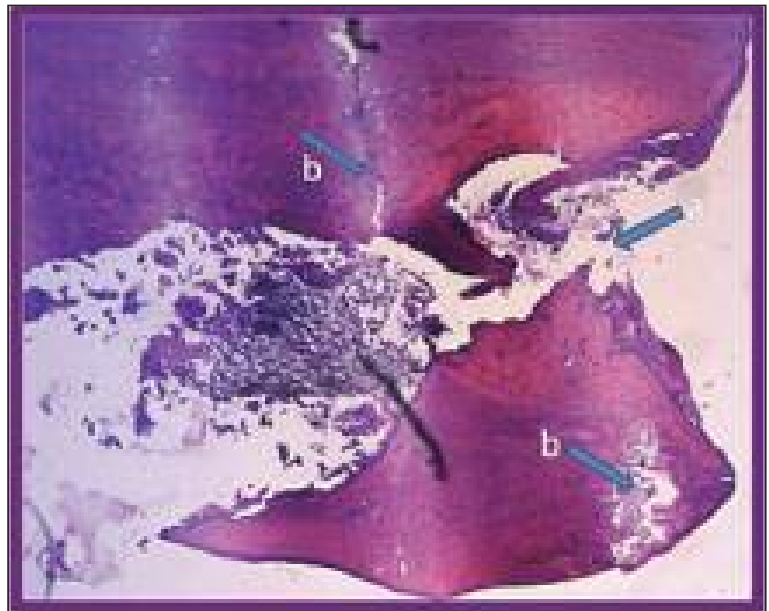

FIGURE 3: (a) A large cleft from the outer layer to the pulp, (b) narrower clefts (H\&E, x5)

nomality usually involves maxillary unilateral contiguous teeth, mostly in females. ${ }^{7,13,14}$ Contrary to the previous cases, the present case has uncommon findings since the involved tooth was a single primary mandibular tooth in a male patient. However, variations of the abnomality including involvement of male patients, affected bilateral mandibular teeth and skipping of the adjacent teeth have been shown in some cases. ${ }^{2,3,10,14,15}$ The abnomality may rarely be restricted to a single tooth as in the present case. ${ }^{16,17}$

Failed, delayed or partial eruption are the characteristic features of $\mathrm{RO}$ cases. ${ }^{2,18,19}$ The interesting aspect of the present case was the history given by the

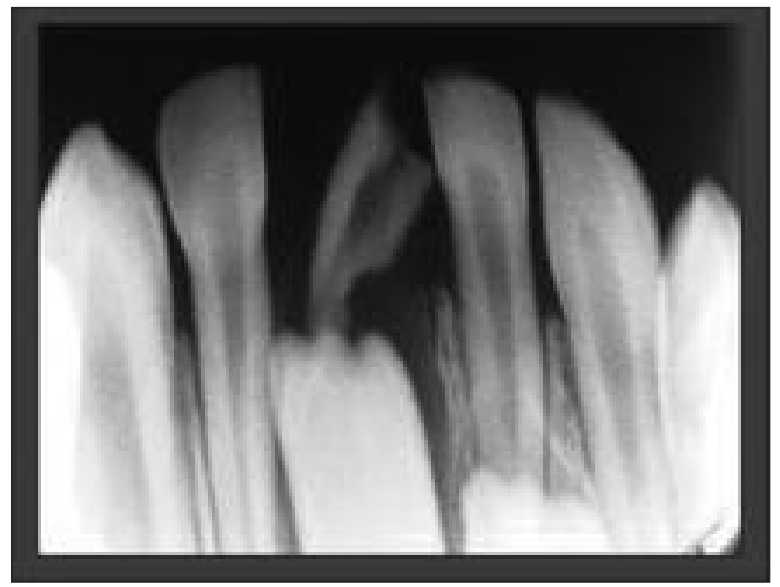

FIGURE 2: Periapical radiograph of the patient.

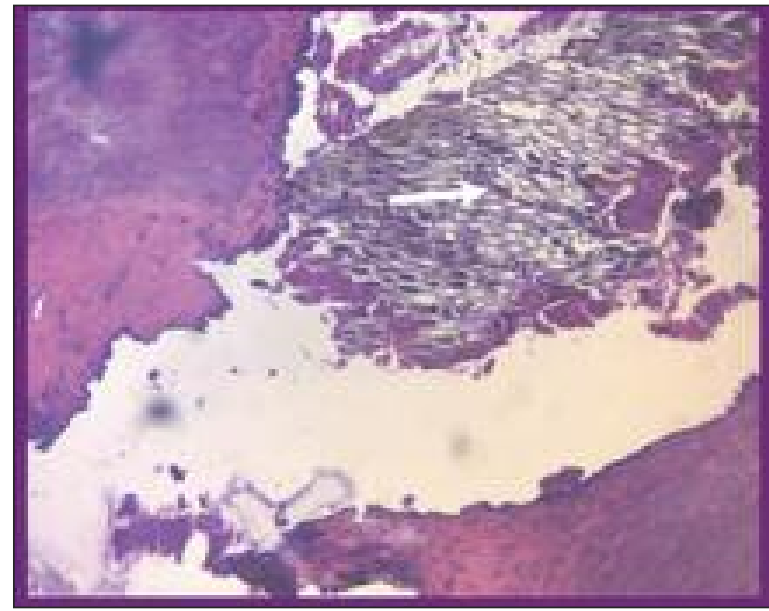

FIGURE 4: A large calcified globule in the pulp chamber stained as gray (arrow) (H\&E, x10)

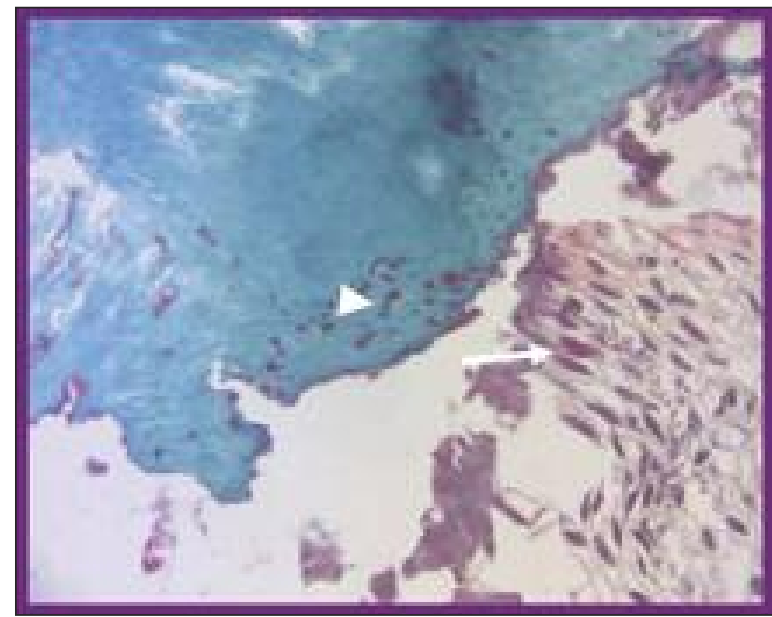

FIGURE 5: Calcified globule (arrow) and calcified dentin areas (arrow head) stained red-brown (MT, x20) 


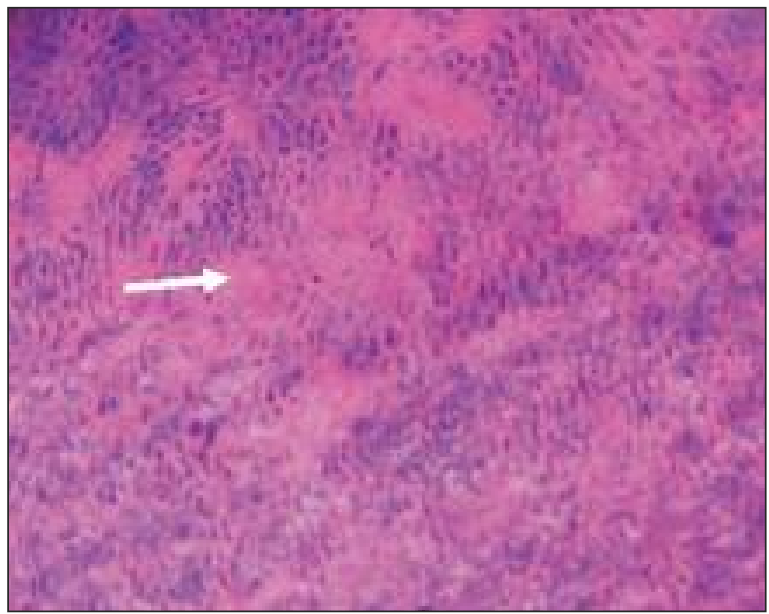

FIGURE 6: Degenerative dentin tubules and interglobuler dentin (arrow) (H\&E, X40)

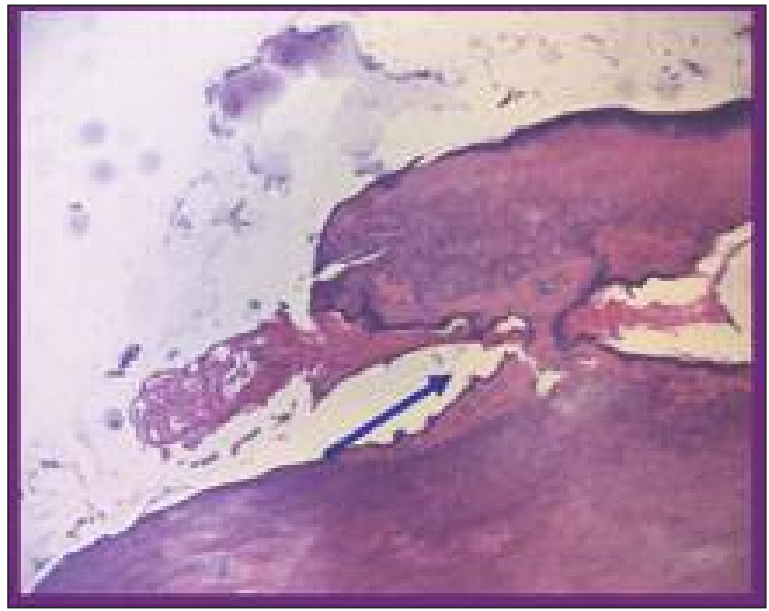

FIGURE 8: Calcified areas in the apical part of the root (arrow) (H\&E, x10)

parents regarding the eruption of the involved tooth in a normal time period with a narrower shape. The radiographical evaluation of the tooth did not reveal a narrower appearance compared to the other central incisor. However, it was considered that the parents might have regarded the tooth as narrower than the others as the tooth was partially erupted.

Another interesting finding of the present case was the yellow-brown discoloration of the involved tooth after eruption. This finding was also reported by Gerlach et al. ${ }^{3}$ whereby the authors did not comment on the issue.

Since the present case was unusual, he was evaluated in detail including history, clinical, radi-

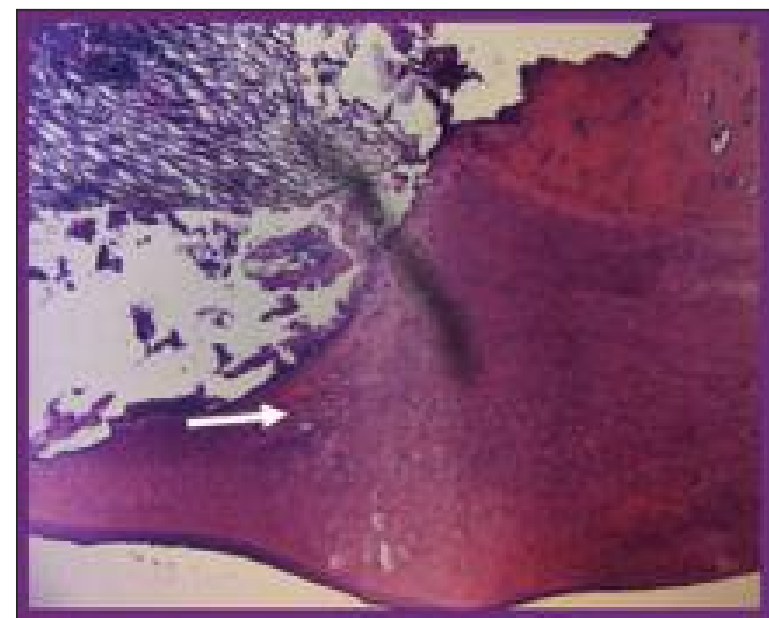

FIGURE 7: Enlarged predentin layer (arrow) (H\&E, x10)

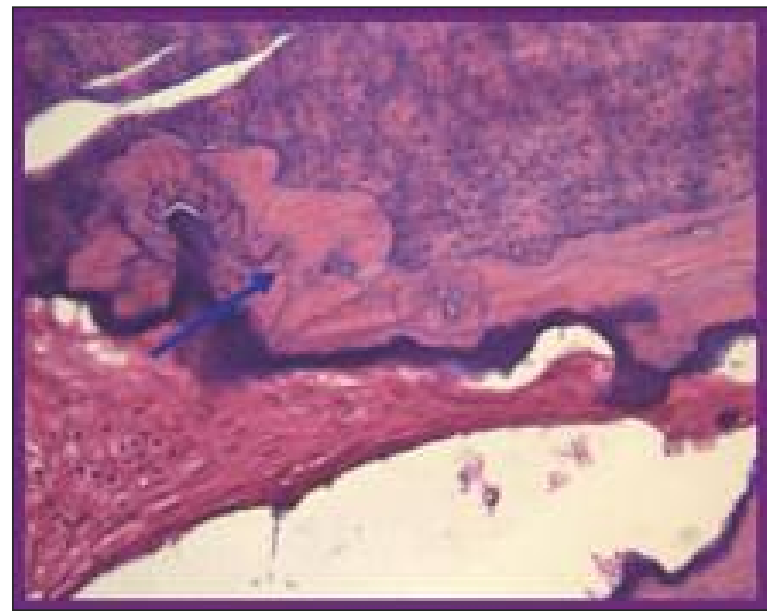

FIGURE 9: Calcifying connective tissue areas in the apical part of the root (arrow) (H\&E, x 40)

ographical and histological examinations in order to confirm RO diagnosis and evaluate whether there were additive effects of trauma on typical $\mathrm{RO}$ features. Radiographically, the affected tooth demonstrated typical signs of RO. Hence, the enamel and dentin were less radio-opaque than the other primary teeth and the demarcation between enamel and dentine was not distinct. ${ }^{6,7,20}$ The root was short but the root canal was not enlarged as reported in some cases in the literature. ${ }^{20} \mathrm{~A}$ cleft extending from the incisal edge down to the pulp was visible even radiographically, and it was also detected histologically. ${ }^{8}$ The clefts have abnormal dentin matrix with no collagen formation. ${ }^{18,19,21}$ The 
absence of any sign of carious tooth tissue and bacteria in the present case also revealed the role of clefts in entrance of bacteria and formation of pulpitis and abscess. ${ }^{4,18}$

Reduced enamel and dentin thickness and radiodensity along with wide pulp chamber give the appearance of ghost tooth in RO cases. ${ }^{2,5,20}$ However, in the present case the cleft might have also been a factor for the extra widening of the pulp chamber since a resorption cavity in the mesial aspect of the root, loss of lamina dura and the surrounding alveolar bone were detected as well. Previous trauma could have a role on the enlargement of the cleft and the above findings because the parents reported that abscess formation had begun after trauma although it is usual in RO cases. ${ }^{5,6}$ Nevertheless, traumatic injury was not regarded as a major causative factor since the trauma happened after the eruption of the tooth.

In parallel with the reported histological findings of $\mathrm{RO}$, the pulp was necrotic and a large irregular and calcified mass was detected in the pulp chamber. ${ }^{14}$ In order to find out whether the mass contained only calcified tissue, it was also stained with MT. Staining with MT revealed that the glo- bular mass contained calcified areas like some areas in dentin since both were stained as red-brown. The additive role of trauma on the calcification or extension of the globular mass is of concern since trauma can result in mineralized deposits in the pulp chamber. ${ }^{22}$

Hypoplastic enamel with degenerated globular calcifications and irregular enamel prisms are characteristic findings of RO. ${ }^{4,23}$ However, in the present case, enamel could not be evaluated probably because of the decalcification procedures. ${ }^{14}$ Irregular interglobular dentin and calcified globular masses between the dentinal tubules, extended predentin layer, reduced number of the dentinal tubules with irregular courses were detected compatible with the existing literature. ${ }^{5,7,14}$ Radicular dentin was much more normal in structure and calcification. ${ }^{3}$ Foci of calcification were detected in connective tissue in the apical area.

All of the aforementioned histological findings confirmed clinically and radiographically established diagnosis of RO. Histological examination may be needed in cases with unusual features in order to diagnose RO cases, and would help to determine the prevalence of the condition. ${ }^{20}$

\section{REFERENCES}

1. Courson F, Bdeoui F, Danan M, Degrange M, Gogly B. Regional odontodysplasia: expression of matrix metalloproteinases and their natural inhibitors. Oral Surg Oral Med Oral Pathol Oral Radiol Endod 2003;95(1):60-6.

2. Cho SY. Conservative management of regional odontodysplasia: case report. J Can Dent Assoc 2006;72(8):735-8.

3. Gerlach RF, Jorge J Jr, de Almeida OP, Coletta RD, Zaia AA. Regional odontodysplasia. Report of two cases. Oral Surg Oral Med Oral Pathol Oral Radiol Endod 1998;85(3):308-13.

4. Crawford PJ, Aldred MJ. Regional odontodysplasia: a bibliography. J Oral Pathol Med 1989;18(5):251-63.

5. Guzman R, Elliott MA, Rossie KM. Odontodysplasia in a pediatric patient: literature review and case report. Pediatr Dent 1990;12(1):45-8.

6. Cahuana A, González Y, Palma C. Clinical management of regional odontodysplasia. Pediatr Dent 2005;27(1):34-9.
7. Tervonen SA, Stratmann U, Mokrys K, Reichart PA. Regional odontodysplasia: a review of the literature and report of four cases. Clin Oral Investig 2004;8(2):45-51.

8. Fanibunda KB, Soames JV. Odontodysplasia, gingival manifestations, and accompanying abnormalities. Oral Surg Oral Med Oral Pathol Oral Radiol Endod 1996;81(1):84-8.

9. Rushton MA. Odontodysplasia: "ghost teeth". Br Dent J 1965;119(3):109-13.

10. Spini TH, Sargenti-Neto S, Cardoso SV, Souza KC, de Souza SO, de Faria PR, et al. Progressive dental development in regional odontodysplasia. Oral Surg Oral Med Oral Pathol Oral Radiol Endod 2007;104(3):e40-5.

11. Hanks PA, Williams B. Odontodysplasia: report of two cases. Pediatr Dent 1998;20(3): 199-203.

12. Kale $S$, Kocadereli I, Atilla $P$, Aşan E. Comparison of the effects of 1,25 dihydroxycholecalciferol and prostaglandin E2 on orthodontic tooth movement. Am J Orthod Dentofacial Orthop 2004;125(5):607-14.

13. von Arx T Autotransplantation for treatment of regional odontodysplasia. Case report with 6year follow-up. Oral Surg Oral Med Oral Pathol Oral Radiol Endod 1998;85(3):304-7.

14. Hamdan MA, Sawair FA, Rajab LD, Hamdan AM, Al-Omari IK. Regional odontodysplasia: a review of the literature and report of a case. Int J Paediatr Dent 2004;14(5):363-70.

15. Oncag O, Eronat C, Sen BH. Regional odontodysplasia: a case report. J Clin Pediatr Dent 1996;21(1):41-6.

16. Pullon PA, Miller AS. Ghostlike tooth. Gen Dent 1984;32(6):521,526.

17. Eversole LR. Dental Defects. Clinical Outline of Oral Pathology. Diagnosis and Treatment. $3^{\text {rd }}$ ed. Philadelphia: Lea \& Febiger; 1992. p.341-77.

18. Gardner DG. The dentinal changes in regional odontodysplasia. Oral Surg Oral Med Oral Pathol 1974:38(6):887-97. 
19. Gardner DG, Sapp JP. Regional odontodysplasia. Oral Surg Oral Med Oral Pathol 1973;35(3):351-65.

20. Marques AC, Castro WH, do Carmo MA. Regional odontodysplasia: an unusual case with a conservative approach. Br Dent J 1999;186 (10):522-4.
21. Gardner DG, Sapp JP. Ultrastructural, electron-probe, and microhardness studies of the controversial amorphous areas in the dentin of regional odontodysplasia. Oral Surg Oral Med Oral Pathol 1977;44(4):549-59.

22. Mjör IA. Pulp-dentin biology in restorative dentistry. Part 5: Clinical management and tissue changes associated with wear and trauma. Quintessence Int 2001;32(10):77188.

23. Hintz CS, Peters RA. Odontodysplasia. Report of an unusual case and a review of the literature. Oral Surg Oral Med Oral Pathol 1972;34(5):744-50. 